\title{
HEAVY METALS PHYTOREMIDIATION POTENTIAL OF NAPIER GRASS CULTIVATED ON TANNERY SLUDGE IN BANGLADESH
}

\author{
Md. Ariful Islam Juel ${ }^{* 1,2}$, Thuhin Kumar Dey ${ }^{1}$, Md. Ibrahim Sardar Akash ${ }^{1}$ and Kushol Kumar Das ${ }^{1}$ \\ ${ }^{1}$ Leather Engineering Department, Khulna University of Engineering \&Technology, Bangladesh \\ ${ }^{2}$ Civil and Environmental Engineering Department, The University of North Carolina at Charlotte, USA
}

Received: 03 November 2019

Accepted: 16 November 2020

\begin{abstract}
Phytoremediation is a cost effective and eco-friendly method for cleanup of contaminated soil. This study focused on the assessment of phytoremediation potential of Napier grass (Pennisetum purpureum) and Indian mastered (Brassica juncea) yielding in tannery sludge. Initial characterization of tannery sludge showed a high concentration of chromium, lead, copper and zinc which were $6845.5 \pm 50.2,73 \pm 2.5,93 \pm 1.5$ and $29 \pm 2.5 \mathrm{mg} / \mathrm{kg}$, respectively. Both seeds of these plants were sown on tannery sludge kept in baskets and harvested after 8 and 12 weeks of plantation. Analysis indicated that both Napier grass and Indian mustard accumulated heavy metals in the order of $\mathrm{Cr}>\mathrm{Zn}>\mathrm{Cu}>\mathrm{Pb}$ at different parts of these plants. Transfer factor (TF) for both plants were greater than 1 for $\mathrm{Cu}, \mathrm{Zn}, \mathrm{Pb}$ though it was less than 1 for $\mathrm{Cr}$. Indian mustard accumulated highest concentration of $\mathrm{Cr}, \mathrm{Cu}$, and $\mathrm{Pb}$ whereas Napier grass showed highest $\mathrm{Zn}$ uptake and good $\mathrm{Cr}$ and $\mathrm{Cu}$ accumulation capacity. The uptake rate of $\mathrm{Cr}$ increased in Napier grass with the increase of plant age. Moreover, Napier grass is one of the rapid yielding tropical grasses and can retain for a longer period than Indian mustard for that attribute, it may accumulate more heavy metals than Indian mustard within its life span. Both of these plants can be used for remediating heavy metals from contaminated tannery sludge.
\end{abstract}

Keywords: Napier grass; Indian mustard; remediation; Chromium; Phytoextarction; Tannery sludge.

\section{INTRODUCTION}

Tannery sludge generated from the tannery wastewater treatment plant usually contains considerable amount of heavy metals as most of the tanning processes adopt basic chromium salt, different dyes, pigments, syntans for the leather production. (Juel et al., 2017). Though many tanning industries of developed countries have facilities for separating out chromium, the most used heavy metals in leather manufacturing process, from wastewater and reuse them in the main process, most of the tanneries in Bangladesh as of 2020 either don't have chrome recovery plant or not in operational due to associated with high installation and operational cost, lack of awareness of sustainable development as well as weak law enforcement policy regarding waste management. As a result high concentration of chromium along with other heavy metals are fated into the tannery sludge (Juel et al., 2016). Due to the non-biodegradable in nature these kinds of heavy metals remain in the environment for a long time and accumulate in soil, water and contaminate the food chain at later (Ali et al., 2013). There are different sludge management methods developed such as reuse in brick manufacturing process as a partial replacement of soil (Juel et al., 2017), stabilization in the concrete block (Swarnalatha et al., 2006), manufacturing of compost incorporation with cattle manure, saw dust (Ahmed et al., 2007) though Hossain et al. (2020) reported unsuitability of compost especially with high chromium rich tannery sludge. However, the most used method adopted for the tannery sludge management is landfilling, though it is not properly followed in Bangladesh, instead they dispose it off here and there without any pre-treatment. But this can alter the physicochemical properties and fertility of the soil. When crops are grown on such kind of contaminated soil, the heavy metal can be accumulated in its vegetative parts with incorporation into the food chain and leading to bio-amplification (Pergent and Martini, 1999). These metals are toxic and can form irreversible effects even at low concentration Moreover, Heavy metals can cause oxidative stress by the generation of free radicals which can disrupt cell's inherent antioxidant defenses and can cause cell damage (Das et al., 2008; Mudipalli, 2008). It's imperative to recover metals from the soli in order to mitigate the contamination of ecosystem as well as environment. But it's not a facile task with respect to cost and technical complexity (Barceló and Poschenrieder, 2003). Different kinds of physical, chemical and biological techniques are used for this purpose. The traditional processes are soil incineration, excavation, soil washing, soil flushing, solidification, and stabilization of electrokinetic systems (Sheoran et al., 2011). But these physical and chemical methods have some basic limitations like high cost, intensive labor, irreversible changes in soil properties and disturbance of native soil microflora (Ali et al., 2013). As a result, it's inevitable to find out cost effective, efficient and environment friendly remediation methods for the decontamination of heavy metal-polluted soils. In that scenario, Phytoremediation is a cost effective and eco-friendly technique which can be a good alternative to treat or stabilize hazardous wastes. Plants are supplied with the ability to corrupt the toxins in their vegetative parts and by this way it's possible to expel, exchange and stabilize heavy metals from the contaminated soil (Salt et al., 1998). This 
process of heavy metal extraction utilizes a particular group of plants known as hyper-accumulators. The hyperaccumulator plant species have 100 times higher capability to accumulate metals than those typically found in common plants (Choudhury et al., 2015).

In this study, Indian mustard (Brassica Juncea) and Napier grass (Pennisetum Purpureum) were employed to investigate their phytoremediation potential cultivated on tannery sludge. Both plant species are widely available in Bangladesh. Indian mustard is a well-known hyper-accumulator plant for its abnormal heavy metals extraction capacity from the soil (Choudhury et al., 2015). In recent, Napier grass (Pennisetum Purpureum) has drawn attention in phytoremediation as it has long and deep root system, which is resistive and capable to sustain in a variety of extreme climatic and edaphic condition. Very few researchers investigated Napier grass in phytoremediation of heavy metals cultivated in contaminated sites. Ishii et al. (2015) investigated Cadmium phytoremediation capacity of Napier grass cultivated in Japan. Moreover, both Indian mustard and Napier grass were not studied to investigate their performance cultivated in high concentration of chromium contaminated site like tannery sludge. The purpose of this study is to evaluate the growth capability and heavy metal uptake capabilities of Napier grass from heavy metal rich tannery sludge and compared with that of Indian mustard grown in the same tannery sludge.

\section{METHODOLOGY}

\subsection{Collection and preparation samples}

Tannery sludge was collected from sludge dumping site of Apex Tannery Ltd, unit-2, Gazipur, Bangladesh. After collection, the sludge was dried to drive out extra moisture and the sample was prepared for seedling. Seeds of Indian mustard \& Napier grass were collected from local market. Then the seed samples were sown in two different pots containing sludge sample. The seeds were grown through proper care and the plant samples were harvested after $8^{\text {th }}$ and $12^{\text {th }}$ weeks of plantation. The samples were then washed with distilled water and then sorted into three parts: roots, shoots, and leaves. After grinding and homogenization the samples were stored in refrigerated condition $\left(4^{\circ} \mathrm{C}\right)$ in sealed container until the next analysis.
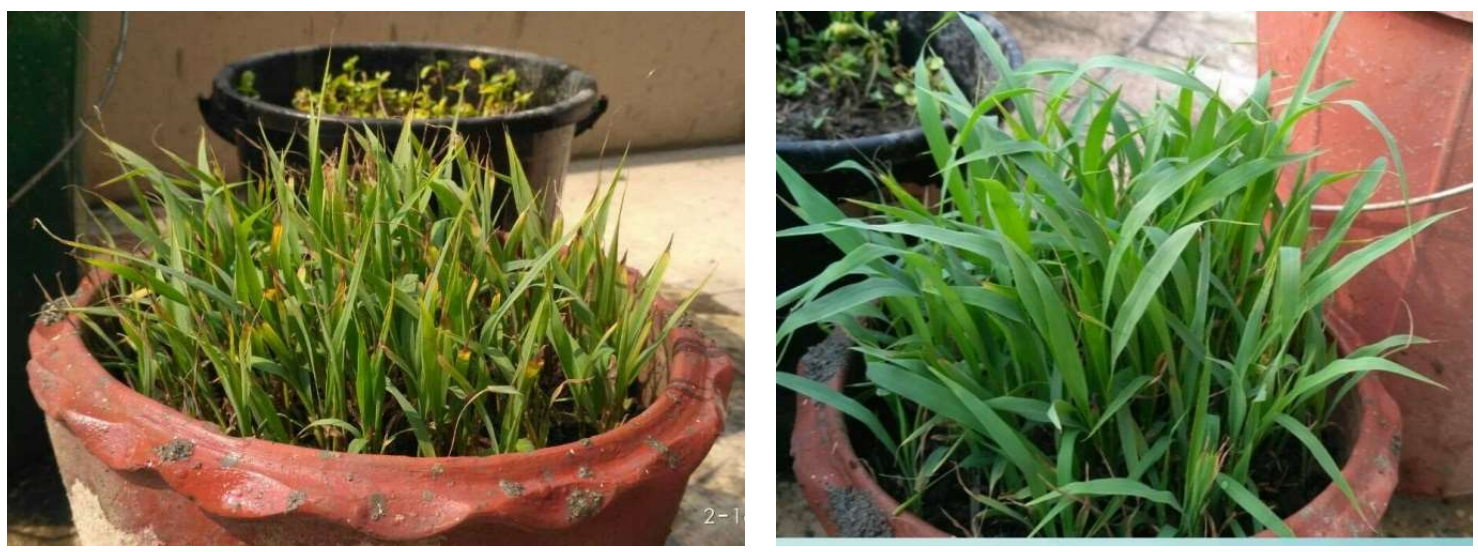

Figure 1: Growth of Napier grass after $8^{\text {th }}$ and $12^{\text {th }}$ weeks
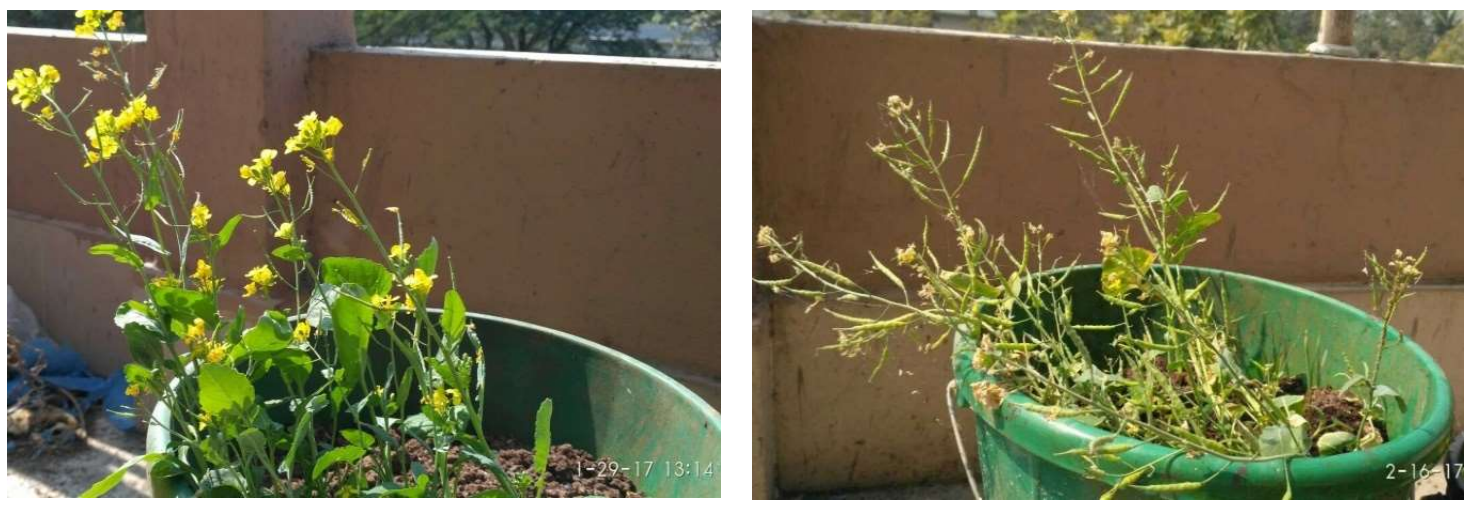

Figure 2: Growth of Indian mustard after $8^{\text {th }}$ and $12^{\text {th }}$ weeks 


\subsection{Heavy metal analysis}

\subsubsection{Digestion for plant analysis}

$0.5 \mathrm{~g}$ of pulverized sample was taken in a $200 \mathrm{ml}$ beaker where $5 \mathrm{~mL}$ of concentrated Nitric acid $\left(\mathrm{HNO}_{3}\right)$ was added. The sample containing beaker was left overnight covering with the watch glass. In the next morning, the covered beaker was heated at $125{ }^{\circ} \mathrm{C}$ for an hour and then allowed to cool. The digestion was continued at the same temperature with the presence of $1-2 \mathrm{~mL}$ of $30 \% \mathrm{H}_{2} \mathrm{O}_{2}$ until the digest was clear. When the digested sample was clear, temperatures was reduced to $80^{\circ} \mathrm{C}$ and continue heating until dryness. Then diluted nitric acid and deionized water were added at a ratio of 1:2 to dissolve digest residue and bring sample to final volume of $50 \mathrm{ml}$. Finally, the sample was filtered through a $0.45 \mu \mathrm{m}$ filter paper and preserved for the analysis of $\mathrm{Cr}, \mathrm{Cu}$, $\mathrm{Zn}$, and $\mathrm{Pb}$ by Atomic Absorption Spectrophotometer (AAS) (Shimadzu AA 6800).

\subsubsection{Digestion for sludge analysis}

At first, $1 \mathrm{~g}$ of pulverized sample (dry weight) was taken to a beaker. $10 \mathrm{~mL}$ of nitric acid was added and covered with a watch glass. The sample was heated at $95 \pm 5^{\circ} \mathrm{C}$ and refluxed for 15 minutes without boiling followed by allowing the sample to cool. Then $5 \mathrm{~mL}$ concentrated $\mathrm{HNO}_{3}$ was added and again refluxed for 30 minutes at the same temperature. $\mathrm{HNO}_{3}$ was added repeatedly until no brown fumes were emitted indicating the completion of reaction with $\mathrm{HNO}_{3}$. Sample was then allowed to evaporate without boiling until the final

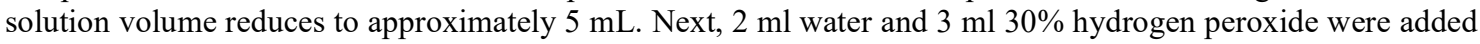
to the sample mixer and started warming again to initiate peroxide reaction. Repeated $30 \%$ hydrogen peroxide addition was continued until either the effervescence was minimal, or sample appearance was unchanged for a while. Finally, the sample volume was reduced to $5 \mathrm{ml}$ followed by the dilution with water and passed through filter $(0.45 \mu \mathrm{m})$. Analysis of $\mathrm{Cr}, \mathrm{Cu}, \mathrm{Zn}$, and $\mathrm{Pb}$ was carried out by Atomic Absorption Spectrophotometer (AAS) (Shimadzu AA 6800).

\subsection{Assessment of Transfer Factor (TF)}

The transfer coefficient was determined by dividing the metal concentration in plants by the total metal present in the soil.

$\mathrm{TF}=$ Cplant $/$ Csoil

Where, Cplant = concentration of uptake metal in plant tissue $(\mathrm{mg} /$ dry weight $)$ and Csoil $=$ metal concentration in soil ( $\mathrm{mg} / \mathrm{kg}$ dry weight).

The ratios greater than one indicates the plant have accumulated that particular metal very well, the ratios around one means the accumulation by the plants are not influenced by that metal, while the ratios less than one show the accumulation has been inhibited. Usually, with the higher TF value the plant is considered as good for phytoremediation (Olowoyo et al., 2010).

\section{RESULTS AND DISCUSSION}

\subsection{Heavy metal contents in tannery sludge}

Table 1 shows the metals concentration in the tannery sludge. It is revealed that chromium persists in the studied sludge with a very high concentration, exceeding the recommended value set by the Department of Environment (DOE) by about eight-fold. It also exceeds the USEPA limit for applying sludge in agricultural land (3000 $\mathrm{mg} / \mathrm{kg} / \mathrm{ha}$ ). Hossain et al. (2020) also reported the unsuitability of tannery sludge compost in the agricultural soil due to high concentration of chromium though it fulfils other criteria of being compost such as nutrient content, $\mathrm{pH}$, organic matter decomposition over the period of time. Other metals concentration in the sludge $(\mathrm{Cu}, \mathrm{Zn}, \mathrm{and}$ $\mathrm{Pb}$ ) were reported lower than the both the restriction limits.

Table 1: Heavy metals concentration in tannery sludge and their permissible limits for utilization

\begin{tabular}{ccccc}
\hline \multirow{2}{*}{ Parameter } & \multicolumn{4}{c}{ Heavy metal concentration of tannery sludge $(\mathrm{mg} / \mathrm{kg}$ dry wt.) } \\
\cline { 2 - 5 } & $\mathrm{Cr}$ & $\mathrm{Cu}$ & $\mathrm{Zn}$ & $\mathrm{Pb}$ \\
\hline Sludge sample & $6845.5 \pm 50.2$ & $73 \pm 2.5$ & $93 \pm 1.5$ & $29 \pm 2.5$ \\
$\begin{array}{c}\text { Permissible limit in } \\
\text { Bangladesh }\end{array}{ }^{\mathrm{a}}$ & 900 & 800 & 2500 & 900 \\
USEPA limit $^{\mathrm{b}}$ & 3000 & 4300 & 7500 & 840 \\
\hline
\end{tabular}

${ }^{a}$ Bangladesh standards and guidelines for sludge management (2015)

${ }^{b}$ USEPA, Land Application of Sewage Sludge. Web link: http//www3.epa.gov/npdes/pubs/sludge.pdf 
Metal concentration order from higher to lower in the sludge is $\mathrm{Cr}>\mathrm{Zn}>\mathrm{Cu}>\mathrm{Pb}$. Relatively higher metal contents were reported in other papers for tannery sludge of Bangladesh (Al-Mizan et al., 2020; Juel et al., 2016). This variation may be due to the variation in the tanning process- vegetable tanning process mostly rely on vegetable extract rather than basic chromium sulfate thereby resulting in the reduced chromium load to the corresponding sludge.

\subsection{Accumulation of Heavy metals in Napier grass}

Both plants grew well on tannery sludge despite having high chromium concentration (Figure 2). At the end of 12 weeks Indian mustard became matured for harvesting while Napier gras was still young and continued growing. For the comparison purpose, both plants were harvested after 12 weeks of plantation. Figure 3 showed the accumulation of $\mathrm{Cr}, \mathrm{Cu}, \mathrm{Zn}$, and $\mathrm{Pb}$ in different part of Napier grass in the time span of 8 and 12 weeks of harvesting. It is revealed that all metal uptake, except lead, in Napier grass increased with the increase of plant age though the accumulation pattern was not same for all these metals. Chromium, Zinc, and Copper accumulation concentration increased by 36,50 and 104\%, respectively in the last 4 weeks of growth compared to the first 8 weeks (Table 2). On the other hand, lead accumulation didn't increase over time which indicates lead accumulation is not favorable in Napier grass, even, may be toxic for the plant. After first 8 weeks of harvesting, chromium uptake was dominant in shoot portion, however, higher metal accumulation concentration shifted from shoot to root after 12 weeks though this apparent higher uptake may not be true while considering total metal uptake in biomass. Because when plant is growing biomass of shoot portion grows faster than that of root resulting in the lower concentration expression in shoot compared to root though total metal uptake still may be dominant in shoot. In case of both Zinc and Lead, the accumulation was almost evenly distributed in different parts of the plant where the maximum accumulation was found in root portion for Copper. Accumulation of all heavy metals in plants grown in garden soil (control) was insignificant.
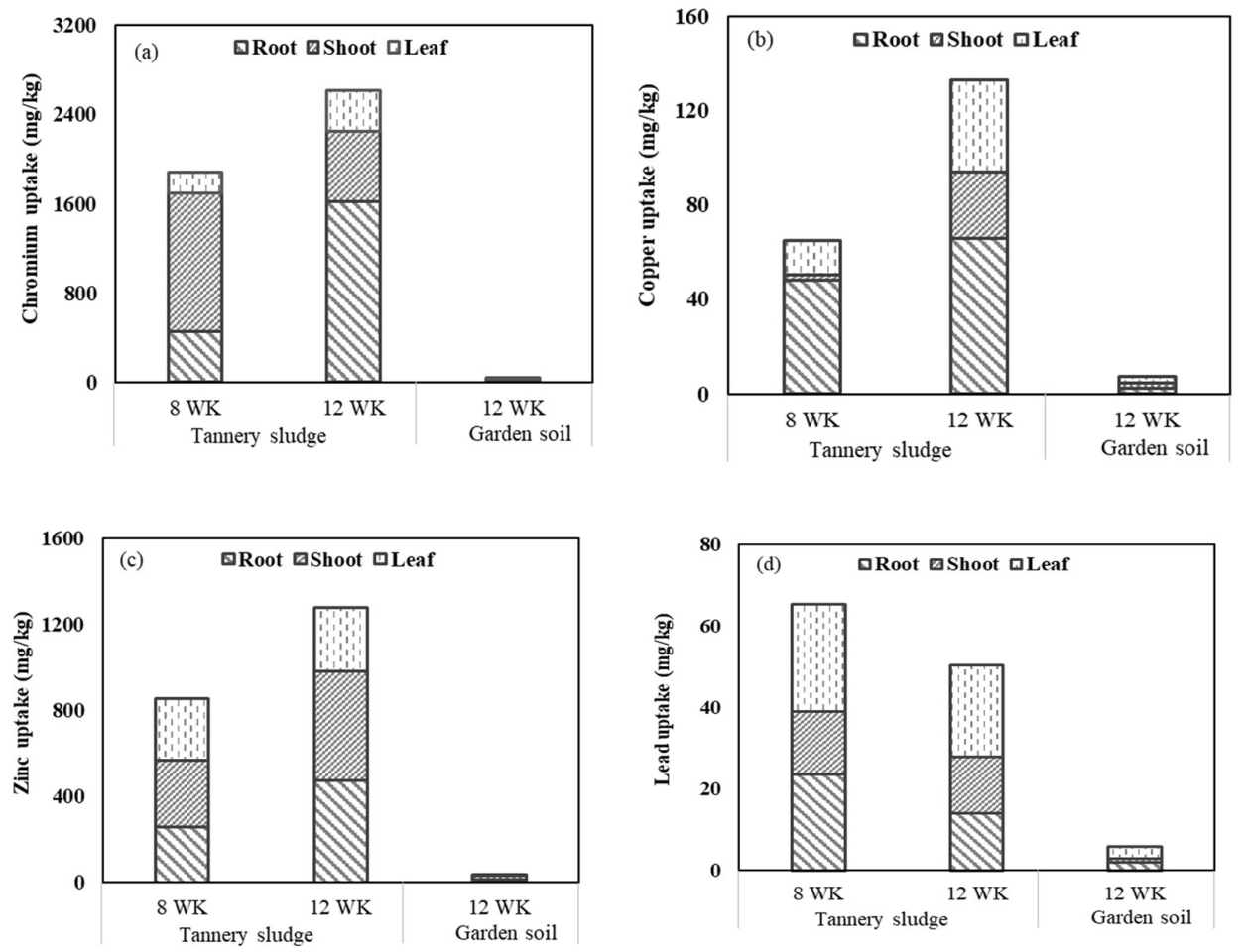

Figure 3: Temporal variation of metals uptake (a) Chromium, (b) Copper, (c) Zinc, (d) Lead in different part of Napier grass.

Figure 4 indicates the comparison of $\mathrm{Cr}, \mathrm{Cu}, \mathrm{Zn}$, and $\mathrm{Pb}$ uptake capacity of Napier grass and Indian mustard after 12 weeks of plantation. It indicated that the magnitude and distribution of these metals were different. The total metal concentration order from higher to lower in both plants is $\mathrm{Cr}>\mathrm{Zn}>\mathrm{Cu}>\mathrm{Pb}$, which varied from one part to another. This order of metal uptake by plants was similar with the order of metal concentration found in sludge. Generally, the process of metal uptake and accumulation by plants depend on the metal richness in soil, solubility sequences and plant species growing on these soils (Sinha et al., 2007). The transport of metals from 
roots to shoot, and leaf includes long distance affected by many factors. The accumulation of $\mathrm{Cr}$ was better in root of Napier plant whereas leaf of Indian mustard showed highest $\mathrm{Cr}$ accumulation. $\mathrm{Cr}$ uptake in different parts (root, shoot, leaf and fruit) varies plants to plants. Gupta and Sinha (2006) reported that the concentration of metals accumulated in root is higher than shoot of Sesamum indicum whereas same author found vice versa for other plants (Gupta and Sinha, 2007). Both plants showed similar pattern in case of $\mathrm{Cu}$, and $\mathrm{Pb}$ accumulation, i.e., highest concentration accounted at lower part of plants. $\mathrm{Zn}$ was almost evenly distributed at lower and upper parts of both plants. Choudhury et al. (2015) also found similar type of pattern in case of $\mathrm{Zn}$ distribution in different parts of Indian mustard and Marigold grown at Buriganga river sediment. The maximum concentration of chromium, copper and lead were accounted in Indian mustard whereas Napier grass showed highest $\mathrm{Zn}$ extraction ability.

Table 2: Accumulation of heavy metals $(\mathrm{mg} / \mathrm{kg})$ in different parts of the Napier grass and Indian mustard after 8 and 12 weeks of plantation.

\begin{tabular}{|c|c|c|c|c|c|}
\hline \multirow{2}{*}{\multicolumn{2}{|c|}{ Parameter }} & \multicolumn{4}{|c|}{ Heavy metals in the sample $(\mathrm{mg} / \mathrm{kg})$} \\
\hline & & \multirow{2}{*}{$\frac{\text { Chromium }(\mathrm{Cr})}{452.1}$} & \multirow{2}{*}{$\frac{\text { Copper }(\mathrm{Cu})}{48}$} & \multirow{2}{*}{$\frac{\text { Zinc }(\mathrm{Zn})}{260}$} & \multirow{2}{*}{$\frac{\text { Lead }(\mathrm{Pb})}{23.7}$} \\
\hline Napier grass & Root & & & & \\
\hline (8 weeks) & Shoot & 1241.6 & 2.4 & 306.1 & 15.3 \\
\hline \multirow{4}{*}{$\begin{array}{l}\text { Napier grass } \\
\text { (12 weeks) }\end{array}$} & Root & 1623.1 & 65.8 & $4 \overline{\bar{q}} \overline{\overline{5}}$ & 14 \\
\hline & Shoot & 629.7 & 28 & 505.9 & 14 \\
\hline & Leaf & 366.4 & 39.3 & 296.5 & 22.4 \\
\hline & Total & 2559 & 133 & 1277 & 50 \\
\hline \multirow{4}{*}{$\begin{array}{l}\text { Indian mustard } \\
\text { (12 weeks) }\end{array}$} & Root & 278.5 & 284.6 & 235.6 & 34.8 \\
\hline & Shoot & 1457 & 69.3 & 222.3 & 47.3 \\
\hline & Leaf & 2169.7 & 58.1 & 403 & 80.3 \\
\hline & Total & 3905 & 412 & 861 & 162 \\
\hline
\end{tabular}
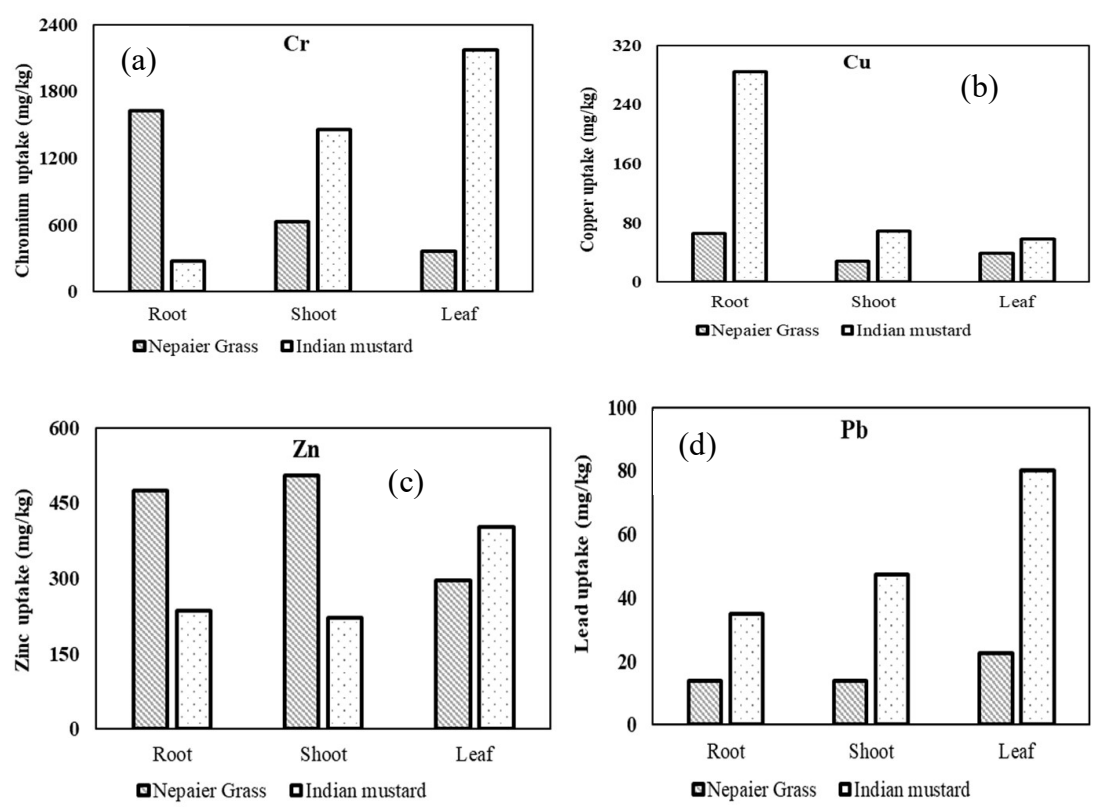

Figure 4: Comparison of heavy metals accumulation in different parts of Napier grass and Indian mustard after 12 weeks of plantation grown on tannery sludge.

\subsection{Transfer Factor in Indian Mustered and Napier Grass}

Accumulation and translocation of heavy metals in the plant depend on the several factors such as types of plant, metal concentration in soil, element species and bioavailability, $\mathrm{pH}$, cation exchange capacity, climatic condition, vegetation period (Filipović-Trajković et al., 2012). From Table 3 it is observed that TF for both plants are greater than 1 in case of $\mathrm{Cu}, \mathrm{Zn}, \mathrm{Pb}$ indicating prospective Phyto extraction potentiality. However, Indian mustered showed better $\mathrm{TF}$ for $\mathrm{Cu}$, and $\mathrm{Pb}$ than Napier grass. On the other hand, Napier grass surprisingly have 1.5 times greater $\mathrm{Zn}$ TF 13.73 (9.3) than Indian mastered. But in case of $\mathrm{Cr}$, the TF is less than 1 for both plants. This may be happened due to the negative relationship between transfer factor and total metal 
concentration in soil and the saturation of $\mathrm{Cr}$ uptake or internal root to shoot migration in the presence of high metal concentration (Sakakibara et al., 2011). In addition, Patel and Patra (2015) also found that translocation factor decreases with the increase of metal concentration of soil. They found the transfer factor for $\mathrm{Cr} 0.70 \mathrm{in}$ case of $50 \%$ sludge which reduced to 0.52 at $75 \%$ sludge content. These findings support the low transfer factor of $\mathrm{Cr}$ in this experiment. Moreover, Napier grass is one of the highest yielding tropical grass in Bangladesh and it can sustain for a longer period than Indian mustards. Harvesting of that plant can continue at an interval of 6-8 weeks for 3-5 years. For its longer life period than Indian mustard it may have more extraction capability of heavy metals.

Table 3 Transfer factor of plants grown in tannery sludge

\begin{tabular}{lcccc}
\hline \multicolumn{1}{c}{ Plants } & Chromium $(\mathrm{Cr})$ & Copper $(\mathrm{Cu})$ & Zinc $(\mathrm{Zn})$ & Lead $(\mathrm{Pb})$ \\
\hline Napier Grass & 0.38 & 1.82 & 13.73 & 1.74 \\
Indian Mustered & 0.57 & 5.64 & 9.3 & 5.6 \\
\hline
\end{tabular}

\section{CONCLUSION}

The results of the present research works showed that both Napier grass (Pennisetum purpureum) and Indian mustard (Brassica juncea) plants were grown well on tannery sludge and accumulated high concentration of heavy metals in different parts of the plant. Indian mustard outperformed Napier grass in accumulating $\mathrm{Cr}, \mathrm{Cu}$, and $\mathrm{Pb}$ whereas Napier grass showed higher $\mathrm{Zn}$ accumulation than Indian mustard. Chromium was accumulated rapidly in Napier grass during the last 4 weeks of growth. Although the $\mathrm{Cr}$ accumulation rate of Napier grass was comparatively lower than Indian mustard for first 12 weeks of plantation, having higher life span and as it showed an increasing trend of accumulation over time, Napier grass may end up accumulating more chromium than Indian mustard. According to the Translocation Factor, Napier grass is a potential plant for phytoremediation of $\mathrm{Cu}, \mathrm{Pb}$, and $\mathrm{Zn}$ as $\mathrm{TF}$ is greater than one for all these metals. Though $\mathrm{TF}$ factor for $\mathrm{Cr}$ is less than one for both plants it is not abnormal especially for high $\mathrm{Cr}$ contaminated site. During the study period, Indian mustard and Napier grass were harvested in the basket for a short period of time and the distribution of the roots of the plants were random within the sludge. Hence no attempt was made to measure the postharvesting changes of heavy metals in soil. To have an idea about the average reduction of heavy metal concentration in sludge more sampling should have been taken, which was not done in the present study. Assessment of heavy metal concentration in sludge sample and multiple plants sample could have given some information about the average lowering of heavy metal concentration in the sludge after application of phytoremediation.

\section{ACKNOWLEDGEMENT}

The authors are thankful to Mr. Mizan, scientific officer, Leather Research Institute for helping in data collection. The authors are highly grateful to Dr. Tanvir Ahmed, Associate Professor, BUET for giving opportunity to determine heavy metals at environmental engineering laboratory, BUET, Bangladesh.

\section{REFERENCES}

Ahmed, M., Idris A., Omar, S.R.S., 2007. Physicochemical characterization of compost of the industrial tannery sludge, J. Eng. Sci. Technol. 2, 81-94.

Al-Mizan, Juel M.A.I., Alam M.S., Pichtel J., Ahmed T., 2020. Environmental and health risks of metalcontaminated soil in the former tannery area of Hazaribagh, Dhaka. SN Appl. Sci. 2. https://doi.org/ $10.1007 / \mathrm{s} 42452-020-03680-4$

Ali, H., Khan E., Sajad M.A., 2013. Chemosphere Phytoremediation of heavy metals — Concepts and applications. Chemosphere 91, 869-881. https://doi.org/10.1016/j.chemosphere.2013.01.075

Barceló, J., Poschenrieder, C., 2003. Phytoremediation : principles and perspectives. Contrib. to Sci. 2, 333-344.

Choudhury, M.R., Islam M.S., Ahmed Z.U., Nayar F., 2015. Phytoremediation of Heavy Metal Contaminated Buriganga Riverbed Sediment by Indian Mustard and Marigold Plants. Environ. Prog. Sustain. Energy. https://doi.org/DOI 10.1002/ep.12213

Das, K.K., Das S.N., Dhundasi S.A., 2008. Nickel, its adverse health effects \& oxidative stress. Indian J Med Res 128, 412-425.

Filipović-Trajković, R., Ilić Z.S., Šunić L., Andjelković S., 2012. The potential of different plant species for heavy metals accumulation and distribution. J. Food, Agric. Environ. 10, 959-964.

Gupta, A.K., Sinha S., 2006. Chemical fractionation and heavy metal accumulation in the plant of Sesamum indicum (L.) var. T55 grown on soil amended with tannery sludge: Selection of single extractants, Chemosphere, 64, 161-173. https://doi.org/10.1016/j.chemosphere.2005.10.016

Hossain, M.Z., Khanam A., Juel M.A.I., Mizan A., 2020. Assessment of the applicability of tannery sludge 
composting in bangladesh, in: 5th International Conference on Civil Engineering for Sustainable Development (ICCESD 2020), Khulna, Bangladesh.

Juel, M.A.I., Chowdhury Z.U.M., Ahmed T., 2016. Heavy metal speciation and toxicity characteristics of tannery sludge, in: AIP Conf. Proc. 1754, 060009. https://doi.org/10.1063/1.4958450

Juel, Md. Ariful Islam, Mizan A., Ahmed T., 2017. Sustainable use of tannery sludge in brick manufacturing in Bangladesh. Waste Manag. 60, 259-269. https://doi.org/10.1016/j.wasman.2016.12.041

Mudipalli, A., 2008. Metals ( Micro nutrients or toxicants ) \& Global Health. Indian J Med Res 128, 331-334.

Olowoyo, J.O., van Heerden E., Fischer J.L., Baker C., 2010. Trace metals in soil and leaves of Jacaranda mimosifolia in Tshwane area, South Africa. Atmos. Environ. 44, 1826-1830. https://doi.org/ 10.1016/j.atmosenv.2010.01.048

Patel, A., Patra D.D., 2015. Phytoextraction capacity of Pelargonium graveolens L'Hér. grown on soil amended with tannery sludge - Its effect on the antioxidant activity and oil yield. Ecol. Eng. 74, 20-27. https://doi.org/https://doi.org/10.1016/j.ecoleng.2014.10.013

Pergent, G., Martini C.P., 1999. Mercury levels and fuxes in Posidonia oceanica meadows. Environ. Pollut. 106, 33-37.

Sakakibara, M., Ohmori Y., Ha N.T.H., Sano S., Sera K., 2011. Phytoremediation of heavy metal-contaminated water and sediment by Eleocharis acicularis. CLEAN - Soil, Air, Water 39, 735-741. https://doi.org/https:// doi.org/10.1002/clen.201000488

Salt, D.E., Smith R.D., Raskin I., 1998. Phytoremediation: Annual review of plant physiology and plant molecular energy. Plant Physiol. Plant Mol. Biol. 49, 643-668.

Sheoran, V., Sheoran A.S., Poonia P., 2011. Role of Hyperaccumulators in Phytoextraction of Metals From Contaminated Mining Sites: A Review, Crit. Rev. Environ. Sci. Technol. 41, 168-214. https://doi.org/ $10.1080 / 10643380902718418$

Sinha, S., Gupta A.K., Bhatt K., 2007. Uptake and translocation of metals in fenugreek grown on soil amended with tannery sludge: Involvement of antioxidants. Ecotoxicol. Environ. Saf. 67, 267-277. https://doi.org/10.1016/j.ecoenv.2006.07.005

Swarnalatha, S., Ramani K., Karthi A.G., Sekaran G., 2006. Starved air combustion-solidification/stabilization of primary chemical sludge from a tannery, J. Hazard. Mater. 137, 304-13. https://doi.org/10.1016/ j.jhazmat.2006.02.006.

(C) 2021 the Authors. Journal of Engineering Science published by Faculty of Civil Engineering, Khulna University of Engineering \& Technology. This is an open access article under the terms of the Creative Commons AttributionNonCommercial-NoDerivatives License, which permits use and distribution in any medium, provided the original work is properly cited, the use is non-commercial and no Modifications or adaptations are made. 